\title{
Implementasi Pendekatan Saintifik Berbasis Media PPT untuk Meningkatkan Motivasi Belajar Peserta Didik pada Tema7 Perkembangan Teknologi di SD Negeri 1 Klepu Kabupaten Temanggung
}

\author{
Farida Mushthofaiyyah*, Ervina Eka Subekti, Kuswandari \\ Pendidikan Profesi Guru, Pendidikan Guru Sekolah Dasar, Universitas PGRI Semarang \\ *Corresponding Author. Email: mushthofaiyyahfarida@gmail.com
}

\begin{abstract}
This study aims to increase students' learning motivation using PPT media through a scientific approach on theme 7 technological developments at SD Negeri 1 Klepu. This research method uses classroom action research with the research subjects being grade 3 students for the 2020/2021 academic year. This research instrument uses observation, questionnaires, and documentation. While the data analysis technique used descriptive analysis. The results of this study indicate that there is an increase in learning motivation for Theme 7 using PPT media through a scientific approach to 3rd grade students of SDN 1 Klepu. This can be seen from the increase in the average percentage of student learning outcomes from cycle I, namely $61 \%$ and $69 \%$. Cycle 2 has increased with the acquisition of the average percentage of students' learning motivation scores from both observation sheets and questionnaires, which is $76 \%$. Cycle 3 experienced a significant increase as seen from the results of the average percentage of students' learning motivation scores from both observation sheets and questionnaires reaching $86 \%$ and $87 \%$, respectively. So that the expected category is the very good category with the criteria of $86 \%-100 \%$ has been achieved.
\end{abstract}

\begin{abstract}
Abstrak: Penelitian ini bertujuan untuk meningkatkan motivasi belajar peserta didik menggunakan media PPT melalui pendekatan saintifik pada tema 7 perkembangan teknologi di SD Negeri 1 Klepu. Metode penelitian ini menggunakan penelitian tindakan kelas dengan subjek penelitiannya ada siswa kelas 3 tahun ajaran 2020/2021. Instrument penelitian ini menggunakan observasi, angket, dan dokumentasi. Sedangkan teknik analisis datanya menggunakan analisis deskriptif. Hasil penelitian ini menunjukkan bahwa terdapat peningkatan motivasi belajar Tema 7 menggunakan media PPT melalui pendekatan saintifik pada peserta didik kelas 3 SDN 1 Klepu. Hal tersebut dapat dilihat dari peningkatan persentase rata-rata motivasi hasil belajar siswa dari siklus I yaitu $61 \%$ dan $69 \%$. Siklus 2 mengalami peningkatan dengan perolehan prosentase rata-rata skor motivasi belajar peserta didik baik dari lembar observasi maupun angket yaitu $76 \%$. Siklus 3 mengalami peningkatan yang cukup signifikan dilihat dari hasil prosentase rata-rata skor motivasi belajar peserta didik baik dari lembar observasi maupun angket masing-masing mencapai $86 \%$ dan $87 \%$. Sehingga kategori yang diharapkan yaitu kategori sangat baik dengan kriteria $86 \%$ - $100 \%$ sudah tercapai.
\end{abstract}

\section{Article History}

Received: 23-05-2021

Revised: 20-06-2021

Accepted: 24-06-2021

Published: 07-07-2021

Key Words: Learning Motivation, PPT Media, Scientific Approach.

\section{Sejarah Artikel \\ Diterima: 23-05-2021 \\ Direvisi: 20-06-2021 \\ Disetujui: 24-06-2021 \\ Diterbitkan: 07-07-2021}

\author{
Kata Kunci: \\ Motivasi Belajar, Media \\ PPT, Pendekatan \\ Saintifik.
}

How to Cite: Mushthofaiyyah, F., Subekti, E., \& Kuswandari, K. (2021). Implementasi Pendekatan Saintifik Berbasis Media PPT untuk Meningkatkan Motivasi Belajar Peserta Didik pada Tema 7 Perkembangan Teknologi di SD Negeri 1 Klepu Kabupaten Temanggung. Jurnal Paedagogy, 8(3), 386-391. doi:https://doi.org/10.33394/jp.v8i3.3896

d. https://doi.org/10.33394/jp.v8i3.3896

This is an open-access article under the CC-BY-SA License.

\section{Pendahuluan}

Belajar adalah suatu proses usaha yang dilakukan oleh seseorang untuk mendapatkan suatu perubahan yang baru sebagai hasil pengalamannya sendiri dalam interaksi dengan lingkungannya. Dalam hal ini, perubahan adalah sesuatu yang dilakukan secara sadar 
(disengaja) dan bertujuan untuk memperoleh suatu yang lebihbaik dari sebelumnya. Menurut Sutikno (2004) kegiatan belajar berlangsung karena adanya tujuan yang akan dicapai seseorang. Tujuan inilah yang mendorong seseorang untuk melakukan kegiatan belajar, sebagaimana pendapat yang dikemukakan oleh Sardiman (2011) bahwa tujuan belajar pada umumnya ada tiga macam, yaitu untuk mendapatkan pengetahuan, penanaman konsep dan keterampilan, dan pembentukan sikap.

Tercapainya tujuan belajar dipengaruhi beberapa faktor seperti perhatian dan motivasi. Perhatian mempunyai peranan yang penting dalam kegiatan belajar. Dari kajian belajar pengolahan informasi terungkap bahwa tanpa adanya perhatian tak mungkin terjadi belajar Disamping perhatian, motivasi mempunyai peranan penting dalam kegiatan belajar. Motivasi adalah tenaga 21 yang menggerakkan dan mengarahkan aktivitas seseorang. Motivasi dapat dibandingkan dengan mesin dan kemudi pada mobil (Gage dan Berliner, 1984).

Berdasarkan hasil observasi pembelajaran di kelas 3 SD Negeri Klepu, guru dalam pembelajaran hanya menggunakan metode ceramah. Menurut guru mengajar menggunakan metodeceramah lebih efisien waktu dan tidak rumit, selain itu keterbatasan fasilitas belajar disekolah menjadi faktor guru tidak dapat menciptakan proses kegiatan pembelajaran yang bervariatif. Kurangnya variasi pembelajaran mengakibatkan motivasi peserta didik dalam mengikuti proses pembelajaran masih rendah. Peserta didik cenderung merasa bosan dan pasif.

Untuk mengatasi masalah siswa tersebut, solusi yang diterapkan yakni dengan menggunakan media pembelajaran power point melalui pendekatan saintifik untuk meningkatkan motivasi dan semangat belajar peserta didik. Pendekatan saintifik (scientific approach) adalah model pembelajaran yang menggunakan kaidah-kaidah keilmuan yang memuat serangkaian aktivitas pengumpulan data melalui observasi, menanya, eksperimen, mengolah informasi atau data, kemudian mengkomunikasikan (Kemendikbud, 2014). Salah satu inovasi teknologi agar pembelajaran menjadi kondusif, menarik serta dapat memancing keaktifan peserta didik. Media pembelajaran power point dapat digunakan guru untuk memotivasi peserta didik agar lebih semangat serta antusias dalam mengikuti kegiatan pembelajaran. Guru dalam memaparkan suatu materi dapat disajikan menggunakan media power point yang interaktif sehingga peserta didik dapat terlibat aktif dalam pembelajaran (Arsyad, 2014; Heryekti, 2021; Saufi \& Rizka, 2021; Setiarini, 2016). Adapun penelitian ini bertujuan untuk meningkatkan motivasi belajar peserta didik menggunakan media PPT melalui pendekatan saintifik pada tema 7 perkembangan teknologi di SD Negeri 1 Klepu Kabupaten Temanggung.

\section{Metode Penelitian}

Penelitian tindakan kelas merupakan proses pengkajian melalui sistem siklus dari berbagai kegiatan pembelajaran. Kemmis dan Mc Taggart (Sugiyono, 2016) menyatakan langkah-langkah PTK dilaksanakan dengan 4 tahapan yaitu perencanaan (Planning), tindakan (Action), pengamatan (Observation) dan refleksi (Reflection). Pelaksanaan penelitian dilakukan melalui 3 siklus, pelaksanaan siklus dihentikan apabila terjadi peningkatan motivasi belajar peserta didik pada pembelajaran sesuai dengan indikator keberhasilan yang telah ditentukan. Siklus I dilaksanakan dalam 2 pertemuan, siklus 2 dilaksanakan dalam 2 pertemuan dan siklus 3 dilaksanakan 2 pertemuan. Tujuan penggunaan desain penelitian ini yaitu apabila terdapat kekurangan atau belum terpenuhinya tujuan maka akan dilakukan 
perbaikan pada perencanaan dan pelaksanaan untuk bisa dilanjutkan pada siklus berikutnya sampai tujuan tercapai.

Subyek penelitian tindakan kelas ini adalah peserta didik kelas 3 SD Negeri $1 \mathrm{Klepu}$ Kabupaten Temanggung semester II Tahun Pelajaran 2020/2021, dengan jumlah 13 peserta didik, terdiri dari 5 peserta didik laki-laki dan 8 peserta didik perempuan. Teknik pengumpulan data dalam penelitian ini menggunakan: (1) Observasi yaitu dengan menggunakan pedoman lembar observasi yang telah dibuat sebelumnya. (2). Angket atau kuesioner merupakan teknik pengumpulan data yang dilakukan dengan cara memberi pernyataan tertulis kepada responden untuk menjawabnya. (3). Studi dokumentasi yang dilakukan dalam penelitian ini yaitu pengambilan foto saat proes pembelajaran berlangsung.

Teknik analisis data yang digunakan dalam penelitian ini analisis data kualitatif digunakan untuk memaknai atau menafsirkan hasil pengamatan, analisis data kuantitatif analisis data ini digunakan untuk menentukan peningkatan motivasi belajar peserta didik. Data yang dianalisis secara kuantitatif berupa angket untuk mengukur motivasi belajar peserta didik dan lembar observasi motivasi belajar peserta didik. Data yang diperoleh dari lembar observasi dan kuesioner motivasi belajar peserta didik dihitung dan diklasifikasikan dengan teknik persentase. Formula yang digunakan untuk menghitung persentase sebagai berikut:

$$
\text { Persentase }=\frac{\text { Skor yang diperoleh }}{\text { SkorMaksimal }} \times 100 \%
$$

Persentase hasil perhitungan dari lembar observasi dan angket diubah kedalam predikat/kriteria hasil penilaian dengan menggunakan tabel pedoman penilaian dibawah ini (Purwanto, 2013).

\begin{tabular}{|l|c|} 
Tabel 1. Kualifikasi Persentase Motivasi Belajar Siswa \\
\hline Persentase & Kriteria \\
\hline Sangat Baik & $86 \%-100 \%$ \\
\hline Baik & $76 \%-85 \%$ \\
\hline Cukup & $60 \%-75 \%$ \\
\hline Kurang & $55 \%-59 \%$ \\
\hline Kurang Sekali & $\leq 54 \%$ \\
\hline
\end{tabular}

\section{Hasil Penelitian dan Pembahasan}

Berdasarkan penelitian tindakan kelas yang sudah dilakukan bahwa motivasi belajar pada peserta didik kelas 3 SD Negeri 1 Klepu dengan penggunaan media PPT melalui pendekatan saintifik dapat meningkat. Peningkatan dapat dilihat dari hasil observasi motivasi belajar oleh observer dan angket motivasi belajar yang diberikan kepada peserta didik. Observasi motivasi peserta didik dilakukan peneliti yang dibantu oleh satu orang observer. Observasi dilakukan kepada seluruh peserta didik kelas 3 SD Negeri 1 Klepu pada saat pembelajaran berlangsung. Pengamatan dilakukan sebanyak 3 siklus. Hasil observasi pada siklus 1, siklus 2 dan siklus 3 menghasilkan persentase skor tiap indikator yang diamati. Kemudian persentase tersebut dihitung skor rata-ratanya. Sehingga ketiga siklus dapat diamati seberapa besar persentase peningkatannya. 
Tabel 2. Perbandingan Observasi Motivasi Peserta Didik

\begin{tabular}{|c|c|c|c|c|}
\hline \multirow{2}{*}{$\begin{array}{c}\text { No } \\
\text {. }\end{array}$} & \multirow{2}{*}{ Indikator Motivasi Belajar } & \multicolumn{3}{|c|}{ Presentase Skor Motivasi Belajar } \\
\hline & & Siklus 1 & Siklus 2 & Siklus 3 \\
\hline 1. & $\begin{array}{l}\text { Adanya hasrat dan keinginan } \\
\text { berhasil }\end{array}$ & $58 \%$ & $65 \%$ & $82 \%$ \\
\hline 2. & $\begin{array}{ll}\text { Adanya dorongan } & \text { dan } \\
\text { kebutuhan dalam belajar } & \end{array}$ & $58 \%$ & $74 \%$ & $80 \%$ \\
\hline 3. & $\begin{array}{l}\text { Adanya harapan dan cita-cita } \\
\text { masa depan }\end{array}$ & $62 \%$ & $79 \%$ & $82 \%$ \\
\hline 4. & $\begin{array}{l}\text { Adanya penghargaan dalam } \\
\text { belajar }\end{array}$ & $64 \%$ & $79 \%$ & $90 \%$ \\
\hline 5. & $\begin{array}{ll}\text { Adanya kegiatan } & \text { yang } \\
\text { menarik dalam belajar } & \end{array}$ & $63 \%$ & $79 \%$ & $90 \%$ \\
\hline 6. & $\begin{array}{l}\text { Adanya lingkungan belajar } \\
\text { yang kondusif. }\end{array}$ & $60 \%$ & $77 \%$ & $94 \%$ \\
\hline & Rata-rata & $61 \%$ & $76 \%$ & $86 \%$ \\
\hline
\end{tabular}

Tabel diatas menunjukan bahwa terjadi peningkatan rata-rata skor motivasi belajar peserta didik pada siklus I, siklus 2, dan siklus 3 berdasarkan hasil pengamatan yang dilakukan oleh observer yang mengacu pada indikator kegiatan belajar peserta didik yaitu : (1) Adanya hasrat dan keinginan berhasil; (2) Adanya dorongan dan kebutuhan dalam belajar; (3) Adanya harapan dan cita-cita masa depan; (4) Adanya penghargaan dalam belajar; (5) Adanya kegiatan yang menarik dalam belajar; (6) Adanya lingkungan belajar yang kondusif. Pada pengamatan tersebut diperoleh rata-rata persentase pada siklus 1 diperoleh $61 \%$, siklus 2 76\% dan pada siklus 3 diperoleh 86\%. Hal ini menunjukkan adanya peningkatan pada persentase motivasi belajar peserta didik pada setiap siklusnya. Pada siklus 3 rata-rata motivasi belajar sudah mencapai $86 \%$, sehingga dapat dikatakan sudah mencapai kategori motivasi belajar yang diharapkan.

Angket dibagikan kepada peserta didik sebanyak tiga kali yaitu pada siklus 1, siklus 2, dan siklus 3. Hal ini bertujuan agar motivasi peserta didik dapat dilihat dari sudut pandang peserta didik. Keberhasilan tindakan dapat dilihat dari selisih antara persentase skor angket motivasi pada siklus 1 , siklus 2 , dan siklus 3 . Pada hasil angket siklus 1 , motivasi belajar peserta didik rata-rata $69 \%$ dan masuk dalam kategori cukup, artinya motivasi belajar peserta didik belum mencapai kriteria kategori yang diharapkan. Pada siklus 2, terjadi peningkatan presentase motivasi belajar pada peserta didik. Dalam kategori baik dengan persentase ratarata $76 \%$. Meski demikian motivasi belajar peserta didik yang diharapkan adalah kategori sangat baik dengan kriteria $86 \%$ - $100 \%$. Pada siklus 3 terjadi peningkatan yang signifikan yaitu dengan rata-rata persentase motivasi belajar peserta didik mencapai $86 \%$ dengan predikat sangat baik.

Berdasarkan uraian di atas, dapat dilihat bahwa ada peningkatan persentase motivasi belajar peserta didik dari siklus 1 sampai siklus 3. Baik indikator yang ada pada lembar observasi maupun angket. Sebagian besar indikator yang digunakan pada keduanya sama. Data yang menunjukan peningkatan skor motivasi dari angket dapat dilihat pada tabel berikut 
Tabel 3. Perbandingan Angket Observasi Motivasi Peserta Didik

\begin{tabular}{|l|l|r|r|r|}
\hline \multirow{2}{*}{ No. } & \multirow{2}{*}{ Indikator Motivasi Belajar } & \multicolumn{3}{|c|}{ Presentase Skor Motivasi Belajar } \\
\cline { 2 - 5 } & \multicolumn{2}{|l|}{ Siklus 1 } & Siklus 2 & Siklus 3 \\
\hline 1. & $\begin{array}{l}\text { Adanya hasrat dan keinginan } \\
\text { berhasil }\end{array}$ & $69 \%$ & $72 \%$ & $76 \%$ \\
\hline 2. & $\begin{array}{l}\text { Adanya dorongan dan } \\
\text { kebutuhan dalam belajar }\end{array}$ & $69 \%$ & $82 \%$ & $77 \%$ \\
\hline 3. & $\begin{array}{l}\text { Adanya harapan dan cita-cita } \\
\text { masa depan }\end{array}$ & $59 \%$ & $72 \%$ & $97 \%$ \\
\hline 4. & $\begin{array}{l}\text { Adanya penghargaan dalam } \\
\text { belajar }\end{array}$ & $72 \%$ & $67 \%$ & $85 \%$ \\
\hline 5. & $\begin{array}{l}\text { Adanya kegiatan yang } \\
\text { menarik dalam belajar }\end{array}$ & $69 \%$ & $79 \%$ & $90 \%$ \\
\hline 6. & $\begin{array}{l}\text { Adanya lingkungan belajar } \\
\text { yang kondusif. }\end{array}$ & $75 \%$ & $83 \%$ & $94 \%$ \\
\hline & \multicolumn{1}{|c|}{ Rata-rata } & $69 \%$ & $76 \%$ & $87 \%$ \\
\hline
\end{tabular}

Berdasarkan penelitian yang telah dilakukan, terlihat adanya peningkatan motivasi belajar peserta didik kelas 3 pada Tema 7 Perkembangan Teknologi. Hal ini membuktikan bahwa penggunaan media PPT melalui pendekatan saintifik dapat meningkatkan motivasi belajar peserta didik. Guru berperan sebagai pembimbing, fasilitator, dan mediator kegiatan pembelajaran yang membantu agar proses pembelajaran peserta didik berjalan dengan baik. Penyajian materi dengan media PPT dapat menciptakan suasana belajar menyenangkan dan meningkatkan motivasi belajar peserta didik, sehingga peserta didik mudah menangkap materi pembelajaran. Setelah penggunaan media PPT melalui pendekatan saintifik pada tema 7 Perkembangan Teknologi, diketahui bahwa motivasi belajar peserta didik meningkat. Diharapkan penelitian ini dapat dikembangkan lebih lanjut, baik guru maupun pengembang pendidikan lainnya, sehingga preses pembelajaran menjadi lebih baik dan tujuan pembelajaran dapat tercapai secara maksimal.

\section{Kesimpulan}

Berdasarkan hasil penelitian yang telah dilakukan dapat disimpulkan bahwa penggunaan media PPT melalui pendekatan saintifik terbukti dapat meningkatkan motivasi belajar peserta didik terhadap materi Tema 7 dengan melakukan praktik pembelajaran 6 kali pertemuan pada 3 siklus yang dilaksanakan oleh peserta didik kelas 3 SD Negeri 1 Klepu. Hal ini didukung oleh data-data berikut yang dilihat dari:

(1) Siklus 1 perolehan prosentase rata-rata skor motivasi belajar peserta didik baik dari lembar observasi maupun angket masing-masing yaitu $61 \%$ dan $69 \%$.

(2) Siklus 2 mengalami peningkatan dengan perolehan prosentase rata-rata skor motivasi belajar peserta didik baik dari lembar observasi maupun angket yaitu $76 \%$.

(3) Siklus 3 mengalami peningkatan yang cukup signifikan dilihat dari hasil prosentase rata-rata skor motivasi belajar peserta didik baik dari lembar observasi maupun angket masing-masing mencapai $86 \%$ dan $87 \%$.

\section{Saran}

Berdasarkan hasil penelitian ini dapat disampaikan saran sebagai berikut, sebaiknya guru melakukan refleksi tentang kelemahan dalam pembelajaran yang dilaksanakan, untuk segera 
dicari pemecahannya dengan diskusi dengan teman sejawat. dalam hal meningkatkan motivasi belajar demi tercapainya tujuan pembelajaran yang telah ditetapkan. Selain itu, diharapkan guru lebih memanfaatkan media PPT dalam kegiatan pembelajaran sehingga pembelajaran lebih menarik, tidak mononton, dan siswa bersemangat mengikuti pembelajaran.

\section{Daftar Pustaka}

Arsyad, A. (2014). Media Pembelajaran. Jakarta: Rajawali Press

Aqib, Zainal, (2006). Penelitian Tindakan Kelas untuk Guru. Bandung: Yrama Widya.

Azhar, (2018). PENGGUNAAN PENDEKATAN SAINTIFIK DALAM PEMBELAJARAN TEMATIK DI SEKOLAH DASAR.

Doyin, Mukh. (2013). Menulis Artikel Ilmiah \& Populer. Cetakan II. Semarang: Bandungan Institute.

Doyin, Mukh. (2013). Tata Tulis Karya Ilmiah. Semarang: Bandungan Institute.

Heryekti Pujingsih, R. (2021). Meningkatkan Motivasi dan Hasil Belajar Matematika dengan Metode Kooperatif Tipe Jigsaw di SMA Negeri 1 Gerung. Jurnal Paedagogy, 8(1), 50-56. doi:https://doi.org/10.33394/jp.v8i1.3196

Kemendikbud. (2014). Pendekatan Saintifik. Dikutip dari Kajian Pustaka.com pada hari Selasa, Tanggal 10 desember 2020 pukul 14.58 WIB.

Kemmis, S., \& McTaggart, R. (2014). The Action Research Planner. Geelong: Deakin University Press.

Kustandi,C. (2013). Media Pembelajaran Manual dan Digital. Bogor: Ghalia Indonesia.

Mutmainah, Chusaery Rusdy Syarif, Yuyu Yuhana. (2018). PENGGUNAAN MEDIA PEMBELAJARAN POWER POINT UNTUK MENINGKATKAN MOTIVASI DAN HASILBELAJAR PESERTA DIDIK SEKOLAH DASAR.

Permendiknas. (2006). Peraturan Menteri Pendidikan Nasional Nomor 22 Tahun 2006 tentang Standar Kompetensi Lulusan.

Purwanto. (2010). Evaluasi Hasil Belajar. Yogyakarta : Pustaka Pelajar

Saufi, I., \& Rizka, M. (2021). Analisis Pengaruh Media Pembelajaran Film Dokumenter Terhadap Motivasi Belajar Siswa. Jurnal Teknologi Pendidikan : Jurnal Penelitian dan Pengembangan Pembelajaran, 6(1), 55-59. doi:https://doi.org/10.33394/jtp.v6i1.3626

Setiarini, A. (2016). Meningkatkan Motivasi dan Hasil Belajar Peserta Didik dengan Mengoptimalkan Penerapan Pendekatan Saintifik Strategi Discovery Learning dan Metode Diskusi di SDN Model Mataram. Jurnal Kependidikan: Jurnal Hasil Penelitian dan Kajian Kepustakaan di Bidang Pendidikan, Pengajaran dan Pembelajaran, 2(1). doi:https://doi.org/10.33394/jk.v2i1.390

Sugiyono. (2016). Metode Penelitian Kuantitatif, Kualitatif, dan R\&D.Bandung: Alfabeta.

Sundayana, R. (2015). Media dan Alat Peraga dalam Pembelajaran Matematika. Bandung: ALFABETA

Sutikno, Sobry. (2004). Menuju Pendidikan Bermutu. Mataram: NTT Press

Syarifah, Ety. (2011). Penelitian Pendidikan untuk Guru. Semarang: Bandungan Institute. 